\title{
Pengaruh Metode Latihan dan Koordinasi Mata-Tangan terhadap Keterampilan Servis Atas Bola Voli
}

\author{
Yohana Bela Christian Sari ${ }^{1}$ *, G. Guntur ${ }^{2}$ \\ ${ }^{12}$ Program Studi Ilmu Keolahragaan, Program Pascasarjana, Universitas Negeri Yogyakarta. Jalan \\ Colombo No. 1, Karangmalang, Yogyakarta, 55281, Indonesia \\ * Korespondensi Penulis. Email: yohanabelachristiansari@yahoo.co.id \\ Received: 27 January 2017; Revised:18 April 2017; Accepted: 21 April 2017
}

\begin{abstract}
Abstrak
Penelitian ini bertujuan untuk mengetahui: (1) perbedaan pengaruh metode massed practice dan metode manipulasi jarak servis terhadap keterampilan servis atas (top spin) bola voli, (2) perbedaan hasil servis atas (top spin) bola voli yang memiliki koordinasi mata-tangan tinggi dan koordinasi mata-tangan rendah terhadap keterampilan servis atas (top spin) bola voli, dan (3) interaksi antara metode latihan dan koordinasi mata-tangan terhadap keterampilan servis atas (top spin) bola voli. Metode penelitian ini menggunakan eksperimen dengan rancangan faktorial $2 \times 2$. Populasi penelitian ini adalah anak latih ekstrakurikuler SMP di Kalasan Sleman Yogyakarta, yang berjumlah 42 orang. Sampel penelitian ini 22 diambil dengan teknik purposive sampling. Instrumen penelitian menggunakan tes koordinasi mata-tangan dan servis atas bola voli dengan menggunakan tes russlle-lange volleyball serve test. Teknik analisis data menggunakan Anava. Hasil penelitian ini menunjukkan bahwa: (1) ada perbedaan pengaruh yang signifikan antara latihan servis atas dengan menggunakan metode latihan massed practice dan metode latihan manipulasi jarak terhadap servis atas (top spin) bola voli, (2) ada perbedaan yang signifikan servis atas (top spin) bola voli antara anak latih yang memiliki koordinasi mata-tangan tinggi dan koordinasi mata-tangan rendah, dan (3) ada interaksi antara metode latihan servis atas dan koordinasi mata-tangan terhadap servis atas bola voli.
\end{abstract}

Kata Kunci: massed practice dan manipulasi jarak, koordinasi mata-tangan, servis atas (top spin) bola voli

\section{The Effects of Training Method and Eye-Hand Coordination on the Results of Volleyball Serving Skill}

\begin{abstract}
This study aims to investigate: (1) the difference of the effects of massed practice method and serving distance manipulation method on the results of volleyball topspin serving skill, (2) the difference of the effects of the volleyball topspin serving with high eye-hand coordination and low eye-hand coordination on the results of volleyball topspin serving skill, and (3) the interaction between the training method and eyehand coordination on the results of volleyball topspin serving skill. The study employed experimental method with $\begin{aligned} & a \\ & 2\end{aligned} \times 2$ factorial design. The research population comprised students joining the extracurricular of volleyball at SMP Kalasan, Sleman, Yogyakarta, with a total of 42 students. The sample consisted of 22 students, selected by means of purposive sampling technique. All data obtained through this study to test and measure eye-hand coordination tests and results of volleyball topspin serving were measured by Russell-Lange volleyball serving test. The data were analyzed by ANOVA. The results of the study are as follows. (1) There is a significant difference of the effects of topspin serving training through the massed practice training method and the distance manipulation training method on the results of volleyball topspin serving. (2) There is a significant difference in the results of volleyball topspin serving between the students with high eye-hand coordination and those with low eye-hand coordination. (3) There is an interaction between the serving training methods and eye-hand coordination on the results of volleyball topspin serving.
\end{abstract}

Keywords: massed practice and serving distance manipulation methods, eye-hand coordination, results of volleyball topspin serving

How to Cite: Sari, Y., \& Guntur, G. (2017). Pengaruh metode latihan dan koordinasi mata-tangan terhadap hasil keterampilan servis atas bola voli. Jurnal Keolahragaan, 5(1), 100-110.

doi:http://dx.doi.org/10.21831/jk.v5i1.12773

Permalink/DOI: http://dx.doi.org/10.21831/jk.v5i1.12773 


\section{Jurnal Keolahragaan 5 (1), April 2017 - 101}

Yohana Bela Christian Sari, G. Guntur

\section{PENDAHULUAN}

Pendidikan dapat diperoleh melalui jalur formal, nonformal, dan informal. Sekolah adalah sebuah wadah atau lembaga formal untuk belajar dan memberikan pelajaran yang disesuaikan dengan kurikulum pendidikan. Di sekolahlah tempat anak menimba ilmu dan juga anak-anak belajar berbagai mata pelajaran yang ke depannya akan menjadi bekal untuk masa depan, begitu pula dengan pendidikan jasmani di sekolah. Agar tujuan yang diharapkan dapat tercapai rasanya kurang jika hanya menggantungkan pada alokasi jam pelajaran saja. Di dalam Undang-Undang No. 20 Tahun 2003 menjelaskan bahwa "Pendidikan nonformal berfungsi mengembangkan potensi peserta didik dengan penekanan pada penguasaan pengetahuan dan keterampilan fungsional serta pengembangan sikap dan kepribadian profesional" (Presiden Republik Indonesia, 2003). Salah satu cara yang dapat ditempuh untuk menunjang agar tujuan yang diharapkan dapat tercapai adalah melalui kegiatan ekstrakurikuler. Kegiatan ekstrakurikuler merupakan salah satu pendidikan nonformal yang diprogramkan di luar jam pelajaran sekolah dan diarahkan untuk membantu ketercapaian program kurikuler.

Kegiatan ekstrakurikuler dilaksanakan di luar jam aktif kegiatan proses belajar mengajar. Biasanya dilaksakan pada sore hari sepulang sekolah. Kegiatan ektrakurikuler adalah kegiatan yang memfokuskan pada salah satu bentuk aktivitas untuk memperdalam keahlian bidang tertentu. Berkiblat pada materi pendidikan jasmani, beberapa jenis kegiatan olahraga permainan yang sering di-ekskul-kan adalah jenis permainan bola besar, seperti bola voli.

Pada dasarnya prinsip bermain bola voli adalah memantulkan bola sebelum menyentuh lantai, bola dimainkan sebanyak tiga kali memantulkan dalam lapangan sendiri secara bergantian dengan mengusahakan bola yang dipantulkan itu diseberangkan ke lapangan lawan melewati atas jaring net dan diusahakan lawan menerima sesulit mungkin. Bola voli dimainkan oleh dua regu tiap regu terdiri atas enam pemain, dan tiap regunya berusaha melewatkan bola di atas net bola voli agar jatuh menyentuh lantai lapangan lawan, kemudian mencegah usaha yang sama dari lawan agar mendapatkan poin atau angka regu yang pertama mencapai angka 25 adalah regu yang menang (Muhajir, 2004, p. 30).
Kegunaan bermain bola voli dalam pembentukan individu secara harmonis antara perkembangan jasmani dan rohani sangatlah besar. Permainan bola voli memiliki gerak yang cukup kompleks, yang membutuhkan koordinasi, kelentukan, kondisi fisik yang baik agar dapat meraih prestasi yang maksimal.

Anak latih yang mengikuti latihan secara rutin akan memperbaiki kualitas koordinasi, kelentukan, dan kondisi fisik, yang pada akhirnya anak latih akan memiliki keuntungan lebih akibat mengikuti kegiatan bola voli tersebut. Anak latih akan lebih mudah mentransfer ke permainan olahraga yang lain. Prestasi pemain akan baik apabila jasmani dan rohani saling terkait didalam gerakan-gerakan bermain, jiwa sebagai pendorong utama untuk menggerakkan kemampuan jasmani yang dimiliki, perkembangan jasmani dimaksudkan untuk membentuk sikap tubuh yang baik meliputi anatomis, fisiologis, kesehatan yang meliputi kalincahan, daya tahan, kekuatan, koordinasi, dan kelentukan.

Dalam permainan bola voli terdapat beberapa teknik yang mendukung jalannya suatu pertandingan salah satu teknik yang sangat mendukung adalah servis. Servis adalah satusatunya teknik yang digunakan untuk memulai permainan. Servis merupakan langkah dasar awal yang harus dikuasai dalam bermain bola voli. Pada saat bermain bola voli, pemain hanya akan mendapatkan angka apabila pemain memegang servis (kecuali saat penentuan di set kelima), karena itulah dalam suatu pertandingan sangat penting bagi pemain untuk melakukan servis dengan konsisten, yaitu paling tidak $90 \%$ dari servis pemain dapat melewati net ke daerah lawan. Pada masa kini, servis bukan sekedar tanda dimulai permainan atau sekedar menyajikan bola, tetapi lebih dari itu servis berarti sebagai serangan pertama bagi regu yang melakukan servis. Ada beberapa jenis servis dalam olahraga bola voli antara lain servis bawah dan servis atas. Salah satunya yang harus dapat dikuasai adalah servis atas (top spin).

Servis atas (upperhand service) adalah servis dengan awalan melemparkan bola ke atas kemudian dipukul dengan mengayunkan tangan dari atas. Servis atas sangat baik digunakan sebagai serangan pertama, karena bola yang dihasilkan dari servis atas tidak mudah diterima oleh pemain lawan, sehingga menjadi sebuah keuntungan yang sangat besar jika menguasai servis atas dengan baik. Anak latih sering mengalami kesulitan untuk dapat menguasai keterampilan servis atas bola voli yang baik dan 
benar. Hal ini disebabkan oleh beberapa faktor yang salah satu di antaranya adalah kurang beragamnya metode latihan yang diterapkan sehingga latihan pun menjadi membosankan dan kurang efektif untuk peningkatan kemampuan anak latih, dan program yang digunakan kurang tepat sasaran sehingga diperlukan metode latihan yang tepat untuk melatih servis atas kepada anak latih. Ditinjau dari tingkat kesukarannya, servis atas memiliki tingkat kesukaran yang cukup baik apabila akan dimanfaatkan sebagai serangan pembuka.

Serasi dengan cara menerimanya yang sukar, cara melakukan servis atas pun sukar untuk dilakukan. Oleh karena itu pelatih dan anak latih yang akan melakukan latihan servis atas harus memiliki cara dan metode latihan yang tepat, serta memiliki hubungan yang harmonis antarkeduanya, agar tujuan latihan dapat tercapai secara sempurna. Seperti-halnya pada kegiatan ekstrakurikuler bola voli yang ada di SMP Negeri 1 Kalasan dan SMP Negeri 3 Kalasan, yang merasa tidak cukup hanya keharmonisan antara anak latih dan pelatihnya saja, tetapi metode latihan juga sangat memengaruhi ketercapaian tujuan latihan servis atas bola voli.

Berdasarkan pengamatan awal peneliti diperoleh data awal, SMP Negeri 1 Kalasan dan SMP Negeri 3 Kalasan merupakan kawasan satu rayon, yang artinya dalam proses kegiatan belajar-mengajar akan cenderung memiliki kegiatan yang serupa. SMP Negeri 1 Kalasan dan SMP Negeri 3 Kalasan juga sama-sama memiliki kegiatan ekstrakurikuler bola voli dengan jumlah anak latih yang hampir sama jumlahnya dan memiliki karakteristik kemampuan dan pertumbuhan yang sama juga.

Kegiatan ekstrakurikuler bola voli pada kedua sekolah ini, ditemukan masalah pada pencapaian tujuan latihan yang diharapkan. Melalui hasil tanya-jawab dengan tiap-tiap pelatih, kekurangan fasilitas dan perlengkapan menjadi masalah yang diutarakan dan disayangkan oleh pelatih. Menurut Suganda \& Suharjana (2013, p. 157) sarana dan prasarana yang tidak lengkap, materi pembelajaran (latihan) yang kurang bervariasi, guru (pelatih) dalam mengajar (melatih) yang monoton, menyebabkan siswa (anak latih) akan cepat bosan, dan menjadi tidak aktif dalam proses belajar mengajar (latihan).

Prestasi yang diperoleh anak latih juga belum maksimal. Sebelumnya, anak latih belum banyak memperoleh pengalaman dalam bertanding. Pada saat penelitian dilaksakan, belakangan mereka tengah menyiapkan diri untuk mengikuti beberapa pertandingan daerah. Hasil tanya-jawab dengan pelatih, ditemui bahwa pelatih tidak membuat program latihan secara tertulis, pelatih hanya mempersiapkan latihan apa saja yang dibutuhkan dan akan dilaksanakan saat berada di lapangan.

Berdasarkan pantauan awal peneliti saat melihat proses latihan, semangat yang dimiliki anak latih sedikit naik turun. Sesekali terlihat aktif, sesekali dijumpai menjadi sangat pasif. Berdasarkan pantauan awal pula, peneliti memperoleh beberapa masalah yang terjadi pada anak latih mengenai kemampuan teknik dasar bermain bola voli. SMP Negeri 1 Kalasan dan SMP Negeri 3 Kalasan sama-sama memiliki masalah pada servis atas khususnya hasil servis atas. Untuk beberapa teknik lain yang belum terlihat dikuasai dan digunakan adalah seperti passing atas, dan blocking, karena teknik tersebut memang sulit dilaksanakan. Fokus peneliti yaitu pada servis atas. Servis bola voli adalah salah satu bentuk serangan awal apabila dilaksanankan dengan baik akan sukar diterima lawan, peluangnya besar untuk menambah poin pada regu sendiri.

Anak latih SMP Negeri 1 Kalasan dan SMP Negeri 3 Kalasan memiliki kesulitan dalam pelaksanaan servis atas tersebut. Berdasarkan observasi awal kurang dari $10 \%$ anak yang mampu melaksanakan teknik servis atas. Hal itu dapat dilihat, ketika anak latih diperintahkan untuk bermain bola voli, anak latih cenderung menggunakan servis bawah dan menghindari untuk melakukan servis atas. Kesukaran yang terdapat pada teknik servis atas dan program latihan yang belum tepat, diduga menjadi pemicu ketidaktercapaiannya tujuan latihan.

Suatu program latihan diharapkan mampu meningkatkan kemampuan atlet yang dilatih. Agar tujuan latihan dapat tercapai, tentu banyak faktor yang memengaruhi, baik faktor dari dalam maupun dari luar. Menurut Harsono (2004, p. 7), training adalah suatu proses yang amat kompleks yang melibatkan variabelvariabel internal dan eksternal, antara lain motivasi, ambisi atlet, kuantitas dan kualitas latihan, volume dan intensitas latihan, serta pengalaman-pengalaman bertanding.

Setiap cabang olahraga termasuk pada cabang bola voli memiliki banyak metode latihan yang digunakan. Terkadang penggunaan metode yang tidak tepat justru akan memberikan dampak yang buruk dan menyebabkan kelesuan dalam diri atlet untuk mengikuti latihan. 
Mencari metode latihan yang tepat dan efektif tidaklah mudah. Metode latihan yang akan digunakan dalam penelitian ini adalah metode latihan massed practice dan manipulasi jarak servis. Kedua metode latihan tersebut memiliki karakteristik yang berbeda, metode latihan massed practice menekankan pada pengulangan servis yang bertahap dan terus menerus pada jarak servis yang sesungguhnya dengan waktu istirahat yang sangat singkat bahkan tidak ada waktu istirahat. Di sisi lain metode latihan manipulasi jarak servis yang bertahap menekankan pada pemberian tahapan jarak servis, dari jarak pendek secara bertahap ditambah sampai jarak sebenarnya. Meskipun demikian, kedua metode latihan tersebut belum diketahui mana yang lebih memberikan pengaruh lebih tinggi terhadap keterampilan servis atas bola voli. Selain metode latihan yang memengaruhi, keterampilan servis atas juga dipengaruhi oleh faktor pemain. Perbedaan kemampuan terutama terjadi karena kualitas fisik yang berbeda. Menurut Rahyubi (2012, p. 209) "Faktor-faktor yang mempengaruhi proses latihan keterampilan gerak adalah faktor internal dan faktor eksternal." Kondisi internal mencakup faktor-faktor yang terdapat pada individu, atau atribut lain yang membedakan pemain satu dengan pemain lainnya.

Bola voli merupakan olahraga yang membutuhkan gerak yang kompleks, seperti power, kelentukan, daya tahan dan koordinasi yang baik. Dalam belajar gerak dasar bola voli tersebut, tiap individu mempunyai kemampuan yang berbeda-beda, seperti memiliki kemampuan koordinasi mata-tangan, antara anak latih yang memiliki koordinasi mata-tangan tinggi dan anak latih yang memiliki koordinasi matatangan rendah keterampilannya juga akan berbeda-beda. Diharapkan pula dengan metode latihan yaitu metode latihan massed practice dan metode latihan manipulasi jarak servis, siswa mampu melakukan servis atas dengan mudah dan lebih baik. Dengan belajar teknik yang sudah dikembangkan diharapkan anak latih mudah untuk melakukan sevis atas tersebut.

Servis atas adalah servis dengan awalan melemparkan bola ke atas kemudian dipukul dengan mengayunkan tangan dari atas. Servis atas (upperhand service) dapat dilakukan dengan menggunakan lompatan, tanpa lompatan, dan dari samping, dan jenis putaran arah bola yaitu servis atas overhand topspin, yaitu bola berputar ke arah dalam. Untuk ukuran pemula adalah servis dengan awalan melemparkan bola ke atas kemudian dipukul dengan mengayunkan tangan dari atas.

Jenis servis atas yang digunakan pada penelitian ini adalah jenis servis atas top spin. Menurut Viera, Fergusson, \& Monti (2000), ada beberapa tahapan dalam melakukan servis atas (top spin) bola voli, yaitu: (1) ambil posisi berdiri di belakang garis lapangan. Posisi kaki salah satunya berada di depan, berat badan menumpu pada telapak kaki bagian depan, dan bahu menghadap net. Kedua lutut ditekuk membentuk sudut tumpul, sedangkan tangan kiri menyangga bola dan tangan kanan memegang bola bagian atas. Pandangan mengarah pada bola yang ada di depan. (2) lambungkan bola ke atas lebih kurang setengah meter di atas kepala, tarik tangan ke belakang atas. Kira-kira tinggi bola dalam jangkauan tangan segera bola dipukul. Pukul bola dengan telapak tangan terbuka dan lengan menjangkau sejauh mungkin. Pandangan terhadap bola pada saat memukul, (3) setelah memukul bola ikuti dengan melangkahkan kaki kanan sebagai gerak lanjutan. Kemudian masuk ke dalam lapangan permainan dan ambil sikap siap normal untuk bermain.

"Training is primarily a systematic athletic activity of long duration, which is progressively and individual graded" (Bompa, 1999, p. 125). Training adalah proses yang amat kompleks yang melibatkan variabel-variabel internal dan eksternal, antara lain motivasi dan ambisi atlet, kuantitas dan kualitas latihan, volume dan intensitas latihan, pengalaman bertanding, dan lain lain (Harsono, 2004, p. 7).

Massed practice involves longer practice sessions with many practice trials during the time period. Massed practice schedules will have fewer practice sessions than distributed practice. When the time between trials is a focus, massed practice will have minimal or short rest periods (Magill, 2011, p. 50). Massed practice adalah metode latihan yang pelaksanaannya tanpa diselingi istirahat atau dengan istirahat dengan waktu yang sangat singkat di antara waktu latihan sampai batas waktu yang ditentukan. Bentuk servis yang dilakukan adalah melakukan servis atas (top spin) berulang-ulang pada jarak servis yang sesungguhnya. Latihan servis atas dengan menggunakan metode latihan massed practice memiliki keunggulan diantaranya: (1) berguna dalam menyesuaikan kegiatan yang benar-benar berat secara otomatis juga akan melatih kekuatan dan daya tahan serta melatih gerak otomatisasi anak latih, (2) cocok untuk pembelajaran pressure exercise, (3) cocok 
untuk mempraktikkan skill yang sifatnya individu, (4) cocok untuk pembelajaran yang benarbenar berat, (5) program pembelajaran jangka pendek.

Latihan servis atas dengan manipulasi jarak servis merupakan bentuk latihan keterampilan yang dilakukan dari cara yang lebih mudah kemudian dilanjutkan ke tahap yang selanjutnya yang semakin sulit, yaitu dengan mengatur jarak servis. Cara yang lebih mudah di sini adalah jarak yang lebih pendek dan secara bertahap ditambah sampai jarak yang sebenarnya. Mengenai cara pengembangan ketepatan salah satu cara pengembangan ketepatan dapat dilakukan dengan jarak sasaran dimulai dari dekat kemudian semakin dijauhkan. Metode latihan manipulasi jarak servis akan diterapkan pada anak latih SMP Negeri 3 Kalasan. Latihan servis jarak bertahap yang akan digunakan oleh anak latih di SMP Negeri 3 Kalasan. Jarak servis akan dibagi menjadi 3 jarak, yang terdekat adalah 3 meter, kemudian 6 meter, 9 meter dan yang terjauh adalah pada jarak servis yang sebenarnya. Peningkatan jarak akan dilaksanakan setelah beberapa kali pertemuan. Begitu juga dengan metode manipulasi jarak servis juga memiliki keunggulan. Latihan servis atas dengan manipulasi jarak servis merupakan bentuk latihan keterampilan yang dilakukan dari cara yang lebih mudah kemudian dilanjutkan ke tahap yang selanjutnya yang semakin sulit, yaitu dengan mengatur jarak servis. Keunggulan dari metode ini adalah latihan servis jarak bertahap akan memberikan dampak yang lebih baik terutama kepada pemain pemula. Selanjutnya kelebihan dari metode ini adalah: (1) memperkenalkan bentuk perlakuan yang mudah dahulu kemudian berangsur-angsur ke perlakuan yang sesungguhnya, (2) memberikan adaptasi pada kekuatan otot sehingga meminimalisasi terjadinya cedera, (3) secara psikologi, anak akan merasa lebih nyaman, karena diawali dengan perlakuan yang mudah, (4) cocok untuk pemula.

Perbedaan secara jelas dari tiap-tiap metode latihan tersebut adalah sebagai berikut: (1) metode latihan massed practice adalah metode latihan yang pelaksanaannya melakukan gerakan berulang tanpa diselingi istirahat atau dengan istirahat secara singkat diantara waktu latihan sampai batas waktu yang ditentukan istirahat, sedangkan metode latihan manipulasi jarak pelaksanaannya diselingi waktu istirahat di antara waktu latihan. (2) metode latihan massed practice dilakukan pada jarak servis yang sesungguhnya yang keunggulannya anak latih dapat melatih kekuatan dan ketepatan dalam melakukan servis, sedangkan metode manipulasi jarak dilakukan pada jarak yang berubah-ubah dari yang terdekat dengan net yaitu 3 meter, 6 meter, 9 meter, dan untuk kemudian pada jarak yang sesungguhnya keunggulannya anak latih akan mengadaptasi dari beban kerja yang ringan kemudian berangsur pada keadaan yang sebenarnya, (3) metode latihan massed practice akan memperbaiki kondisi fisik, gerak otomatisasi, dan teknik anak latih, metode latihan manipulasi jarak servis baik dilakukan pada pemula, (4) metode latihan manipulasi jarak akan membuat anak latih nyaman dan meminimalisir terjadinya cedera akibat beban kerja yang berat dan kelelahan, sedangkan metode latihan massed practice mudah membuat anak merasa lelah. (5) Metode latihan massed practice cocok diterapkan pada anak latih yang memiliki koordinasi mata-tangan tinggi, sedangkan metode latihan manipulasi arak lebih cocok diterapkan pada anak latih yang memiliki koordinasi matatangan rendah.

Salah satu kondisi internal adalah kondisi fisik, kondisi fisik berhubungan dengan koordinasi mata-tangan yang akan mempengaruhi hasil servis atas bola voli. Dengan demikian dapat dikatakan bahwa koordinasi mata-tangan merupakan salah satu prasyarat dalam usaha pencapaian prestasi maksimal bagi peserta didik atau anak latih dalam latihan keterampilan servis atas bola voli. Perbedaan koordinasi mata-tangan dapat menjadi pertimbangan sebagai suatu faktor yang menentukan dalam keterampilan servis atas bola voli.

\section{METODE}

Metode yang digunakan dalam penelitian ini adalah metode eksperimen dengan jenis eksperimen semu karena tidak ada kelas kontrol. Penelitian ini adalah penelitian eksperimen yang bertujuan untuk membandingkan dua perlakuan yang berbeda pada subjek penelitian.

Tabel 1. Kerangka Desain Penelitian

\begin{tabular}{ccc} 
Variabel & \multicolumn{2}{c}{ Metode Latihan Servis Atas } \\
\cline { 3 - 3 } Manipulatif & $\begin{array}{c}\text { Metode } \\
\text { Latihan } \\
\text { Massed }\end{array}$ & $\begin{array}{c}\text { Metode } \\
\text { Latihan } \\
\text { Manipulasi } \\
\text { Jaribut (A2) }\end{array}$ \\
\hline $\begin{array}{c}\text { Kractice } \text { (A1) } \\
\text { Joordinasi Mata- } \\
\text { Tangan Tinggi } \\
\text { (B1) }\end{array}$ & A1B1 & A2B1 \\
$\begin{array}{c}\text { Koordinasi Mata- } \\
\text { Tangan Rendah } \\
\text { (B2) }\end{array}$ & A1B2 & A2B2 \\
\hline
\end{tabular}




\section{Jurnal Keolahragaan 5 (1), April 2017 - 105}

Yohana Bela Christian Sari, G. Guntur

Pemberian treatment akan dilaksanakan di dua sekolah yang berbeda, hal ini dimaksudkan agar dapat mensterilkan atau menentralkan antara metode latihan yang satu dan metode latihan yang lain, karena dalam penelitian ini peneliti tidak mengontrol dan mengawasi sampel setelah selesai berlatih. Setelah membagi kelompok saat pretest dilaksanakan, kemudian untuk penentuan metode latihan yang akan digunakan, kedua metode diundi (random), metode mana yang akan digunakan di SMP Negeri 1 dan metode lain di antaranya yang akan digunakan di SMP Negeri 3.

Tempat penelitian akan dilaksanankan di dua sekolah yaitu di SMP Negeri 1 Kalasan dan SMP Negeri 3 Kalasan, Sleman. Penelitian lapangan dilaksanakan selama sepuluh minggu, pemberian treatment dilaksanakan di dua sekolah. Pemberian treatment selama delapan minggu. Hal ini sesuai dengan pendapat Bompa \& Haff (2009, p. 207), maksudnya adalah agar tubuh beradaptasi dengan beban latihan yang diterima dengan pertemuan 3 kali dalam seminggu setiap sekolahnya. Setiap sekolah dengan jumlah pertemuan treatment adalah 24 kali pertemuan untuk treament, ditambah 2 kali pertemuan untuk melakukan pretest dan posttest dan 1 kali pertemuan untuk mengambil data koordinasi mata-tangan.

Menurut Sudjana (2002, p. 6), "Populasi adalah totalitas semua nilai yang mungkin, hasil menghitung ataupun pengukuran kuantitatifkualitatif, mengenai karakteristik tertentu dari semua anggota kumpulan lengkap dan jelas, yang dipelajari sifat-sifatnya." Pemilihan sekolah yang digunakan sebagai populasi adalah dengan menggunakan teknik purporsive sampling, pemilihan sekolah didasarkan atas pertimbangan bahwa sekolah yang dipilih adalah sekolah yang memiliki kegiatan ekstrakurikuler bola voli dengan karakteristik yang sama. Populasi yang digunakan dalam penelitian ini adalah seluruh anak latih yang mengikuti kegiatan ekstrakurikuler bola voli di SMP Negeri 1 Kalasan dan SMP Negeri 3 Kalasan, Sleman.

Sampel yang digunakan dalam penelitian ini adalah seluruh anak latih putra yang mengikuti kegiatan ekstrakurikuler bola voli di SMP Negeri 1 Kalasan sebanyak 22 orang dan SMP Negeri 3 Kalasan, Sleman sebanyak 20 orang dengan jumlah keseluruhan 42 orang.

Cara pengambilan sampel tersebut yaitu sebelum eksperimen dilaksanakan, populasi sebanyak 42 orang dilakukan tes dan pengukuran koordinasi mata-tangan dengan menggunakan tes koordinasi mata-tangan yang telah dipersiapkan. Tes ini digunakan untuk mengetahui skor awal yang menunjukkan koordinasi matatangan anak latih (putra) yang mengikuti ektrakurikuler. Setelah data koordinasi matatangan terkumpul, langkah pertama dalam analisis adalah untuk mengidentifikasikan kelompok atas dan bawah dengan menggunakan skor tes keseluruhan. Teknik sampling yang digunakan adalah dengan purposive sampling, hal ini dikarenakan sampel yang digunakan menggunakan bagian atas $27 \%$ dan bagian bawah $27 \%$ dari skor keseluruhan setelah diurutkan dari yang tinggi ke yang rendah, SMP Negeri 1 dengan jumlah peserta didik sebanyak 22 orang, di-ranking menggunakan bagian atas $27 \%$ dan bawah $27 \%$ dari skor keseluruhan untuk mendapatkan perlakuan latihan servis menggunakan metode latihan massed practice dan SMP Negeri 3 dengan jumlah peserta didik sebanyak 20 orang diranking menggunakan bagian atas $27 \%$ dan bawah $27 \%$ dari skor keseluruhan untuk kemudian mendapatkan perlakuan latihan servis menggunakan metode latihan manipulasi jarak. Kelompok-kelompok ini disebut kelompok atas dan kelompok bawah, dengan demikian 27\% kelompok atas dan 27\% kelompok bawah dianggap yang terbaik untuk memaksimalkan perbedaan antara dua kelompok (Miller, 2013, p. 68).

Variabel dalam penelitian ini terdiri atas dua variabel bebas (indepedent) dan satu variabel terikat (dependent), dengan rincian sebagai berikut: (1) variabel bebas manipulatif yaitu metode latihan yang terdiri atas dua metode, yaitu: (a) metode latihan massed practice servis atas, (b) metode latihan manipulatif jarak servis, (2) variabel bebas atributif (yang dikendalikan) dalam penelitian ini, terdiri atas: (a) koordinasi mata-tangan tinggi, (b) koordinasi mata-tangan rendah, (3) variabel terikat dalam penelitian ini yaitu keterampilan servis atas.

Menurut Sugiyono (2010, p. 148) Instrumen adalah alat ukur yang digunakan dalam penelitian. Teknik yang digunakan dalam penelitian ini adalah teknik tes dan pengukuran dengan menggunakan instrumen-instrumen sebagai berikut: (1) pengumpulan data koordinasi mata-tangan; tes ini bertujuan untuk mengukur koordinasi mata-tangan (Nurhasan, 2000, p. 84). Pelaksaannya adalah sasaran ditempatkan di tembok setinggi bahu peserta tes. Peserta tes diberi keempatan untuk melempar bola tenis ke arah sasaran dari jarak 2,5 m dan menangkap 
bola kembali dengan menggunkan salah satu tangan, dilakukan sebanyak 10 kali, dan ditangkap oleh salah satu tangan secara bergantian. Skor yang dihitung adalah lemparan yang sah, yaitu lemparan yang mengenai sasaran dan dapat ditangkap kembali, serta pada pelaksanaan lempar dan tangkap bola peserta tidak menginjak garis batas. Sebuah lemparan akan memperoleh poin 1 apabila lemparan tersebut mengenai sasaran dan dapat ditangkap kembali dengan benar. Jumlah skor adalah keseluruhan hasil lempar tangkap bola dengan tangan yang sama dan tangan yang berbeda. Validitas tes adalah 0,851 dan reliabilitas 0,750. (2) Data hasil servis atas bola voli. Tes yang digunakan adalah Russell-Lange Volleyball Serve Test, milik French-Cooper yang digunakan untuk mengukur keterampilan servis atas tingkat junior. Teknik pengumpulan data tentang keterampilan servis atas diperoleh dengan menggunakan tes praktik servis atas. setiap peserta melakukan servis di lapangan bola voli sebanyak 10 kali, nilai servis yang benar sesuai dengan ketentuan peraturan mendapatkan nilai sesuai harga petak sasaran. Pada lapangan terlebih dahulu diberi nilai tertentu sesuai dengan tingkat kesukaran hasil servis atas (Suharno, 1998, p. 69). Pemain melaksanakan giliran servis sebanyak 20 kali servis, giliran pertama melakukan 10 kali servis, diselingi waktu istirahat kemudian melakukan 10 kali servis lagi pada giliran berikutnya. Validitas tes adalah 0,924 dan reliabilitas 0,751 .

Dalam penelitian ini analisis data yang digunakan yaitu analisis statistik. Teknik analisis data yang digunakan dalam penelitian ini dengan menggunakan SPSS 20 yaitu analisis varian (Anava) dua jalur pada taraf signifikansi $\alpha=0,05$, maka sebelum sampai pada pemanfaatan Anava perlu dilakukan uji persyaratan yaitu meliputi: (1) uji normalitas menggunakan uji Shapiro Wilks, dan (2) uji homogenitas varians
Levene Test (Sudjana, 2005, p.261). Setelah dilakukan uji prasyarat, uji hipotesis dilakukan dengan menggunakan Anava dua jalur dan apabila terbukti terdapat interaksi akan dilakukan uji lanjutan yaitu uji pairwise comparisons yaitu dengan menggunakan program software SPSS version 20.0 for windows dengan taraf signifikansi $5 \%$ atau 0,05 .

\section{HASIL DAN PEMBAHASAN}

\section{Hasil}

Hasil yang diperoleh dari penelitian berupa data yang merupakan gambaran umum tentang tiap-tiap variabel yang terkait dalam penelitian. Melalui gambaran umum ini akan tampak kondisi awal dan kondisi akhir dari setiap variabel yang diteliti dengan melakukan pengolahan data setelah data berhasil dikumpulkan selama periode latihan yang telah ditentukan. Berdasarkan Tabel 2 dapat diketahui bahwa kombinasi metode latihan massed practice dengan koordinasi mata-tangan tinggi memiliki nilai rata-rata hasil tes awal sebesar 40,5 dan hasil tes akhir sebesar 83,33 dengan selisih 42,83. Begitu juga kombinasi metode latihan massed practice dengan koordinasi mata-tangan rendah memiliki nilai rata-rata hasil tes awal sebesar 16,1667 dan hasil tes akhir sebesar 30,5 dengan selisih 14,333. Diketahui bahwa kombinasi metode latihan manipulasi jarak dengan koordinasi mata-tangan tinggi memiliki nilai rata-rata hasil tes awal sebesar 42 dan ratarata nilai tes akhir sebesar 46,8 dengan selisih 4,8. Kombinasi metode latihan manipulasi jarak dengan koordinasi mata-tangan rendah memiliki nilai rata-rata hasil tes awal sebesar 16.8 dan nilai rata-rata nilai tes akhir sebesar 39 dengan selisih 22,2. Hal yang dapat disimpulkan dari setiap kombinasi metode latihan dengan koordinasi mata-tangan adalah terdapat peningkatan nilai rata-rata hasil tes servis atas.

Tabel 2. Deskripsi Data Hasil Hasil Servis Atas Bola Voli Berdasarkan Metode dan

\begin{tabular}{ccccc}
\hline $\begin{array}{c}\text { Koordinasi Mata-Tangan } \\
\text { Metode Latihan }\end{array}$ & Koordinasi Mata-Tangan & Statistik & Hasil Tes Awal & Hasil Tes Akhir \\
\hline Massed Practice & Tinggi & Rata-rata & 40.5 & 83.3333 \\
& & SD & 8.01873 & 5.27889 \\
& Rendah & Rata-rata & 16.1667 & 30.5 \\
& & SD & 5.6006 & 7.42294 \\
Manipulasi Jarak & Tinggi & Rata-rata & 42 & 46.8 \\
& & SD & 5.95819 & 4.96991 \\
& Rendah & Rata-rata & 16.8 & 39 \\
& & SD & 5.35724 & 3.53553 \\
\hline
\end{tabular}




\section{Uji Prasyarat}

Data yang akan diuji normalitasnya adalah data hasil tes awal servis atas dan data hasil tes akhir servis atas. Berdasarkan analisis statistik uji homogenitas yang telah dilakukan dengan menggunakan uji Shapiro Wilks diketahui bahwa setiap nilai signifikansi pada tiap-tiap kelompok data menunjukkan bahwa nilai signifikansinya $p$ lebih besar dari $0,05(p>0,05)$ sehingga dapat disimpulkan bahwa setiap kelompok data berdistribusi normal.

Uji homogenitas dilakukan terhadap semua data yang diperoleh baik pada tes awal (pretest) maupun pada tes akhir (posttest). Uji homogenitas dimaksukan untuk menguji kesamaan varian antara kelompok satu dan kelompok lainnya. Berdasarkan analisis statistik uji homogenitas yang telah dilakukan dengan menggunakan Levene Test diketahui bahwa nilai signifikansi Levene Test pada data pretest sebesar 0,502 ini berarti $\mathrm{p}>0,05$ dalam kelompok data pretest memiliki varian yang homogen. Demikian juga dalam data posttest diketahui sebesar 0,306 ini berarti $\mathrm{p}>0,05$ berarti dalam kelompok data posttest memiliki varian yang homogen. Hal ini menunjukkan bahwa nilai pretest maupun posttest adalah homogen.

\section{Pengujian Hipotesis}

Pengujian hipotesis penelitian dilakukan berdasarkan hasil analisis data dan interpretasi analisis varian dua jalur. Analisis varian dua jalur digunakan untuk menguji pengaruh utama (main effect) antara variabel bebas metode latihan dan variabel atribut koordinasi mata-tangan (simple effect) terhadap hasil kaeterampilan servis atas bola voli pada anak latih ekstrakurikuler bola voli SMPN 1 dan SMPN 3 Kalasan Sleman, Yogyakarta. Uji pairwise comparisons ditempuh sebagai langkah-langkah uji rata-rata setelah Anava guna mengetahui secara terperinci rata-rata yang berbeda.

\section{Hipotesis I}

Pengujian hipotesis I dilakukan untuk menjawab hipotesis 1 yang berbunyi "Ada pengaruh yang signifikan antara metode latihan massed practice dan metode latihan manipulasi jarak servis terhadap keterampilan servis atas bola voli pada anak latih ekstrakurikuler bola voli, SMP Negeri 1 Kalasan dan SMP Negeri 3 Kalasan, Sleman".

Nilai signifikansi univariate tests sebesar $0,00<0,05$, karena $\mathrm{p}<0,05$ menunjukkan bahwa terdapat pengaruh yang signifikan antara metode latihan massed practice dan metode latihan manipulasi jarak terhadap hasil servis atas.

Dari analisis uji lanjut diperoleh bahwa ternyata metode latihan massed practice memiliki peningkatan yang lebih baik daripada metode latihan manipulasi jarak servis. Dengan demikian metode latihan massed practice lebih bagus daripada metode latihan manipulasi jarak pada masa sebelum retensi, sebagai hasil fase latihan.

\section{Hipotesis II}

Hipotesis yang menyatakan bahwa "Ada pengaruh keterampilan servis atas antara anak latih yang memiliki koordinasi mata-tangan tinggi dan koordinasi mata-tangan rendah, pada anak latih ekstrakurikuler bola voli, SMP Negeri 1 Kalasan dan SMP Negeri 3 Kalasan, Sleman".

Nilai signifikansi univariant tets sebesar $0,00<0,05$, karena $\mathrm{p}<0,05$ menunjukkan bahwa terdapat pengaruh perbedaan koordinasi mata-tangan terhadap hasil servis atas.

Dari analisis uji lanjut diperoleh bahwa ternyata anak latih yang memiliki koordinasi mata-tangan tinggi memiliki peningkatan yang lebih baik dari pada anak latih yang memiliki koordinasi mata-tangan rendah. Dengan demikian anak latih yang memiliki koordinasi matatangan tinggi lebih bagus dari pada anak latih yang memiliki koordinasi mata-tangan rendah pada masa sebelum retensi, sebagai hasil fase latihan.

\section{Hipotesis III}

Hipotesis III menyatakan bahwa "Ada interaksi antara metode latihan dan koordinasi mata-tangan terhadap keterampilan servis atas (top spin) bola voli pada anak latih ekstrakurikuler bola voli, SMP Negeri 1 Kalasan dan SMP Negeri 3 Kalasan, Sleman".

Berdasarkan hasil perhitungan tes of between-subject effects dapat diketahui bahwa nilai $\mathrm{F}$ untuk interaksi antara metode latihan dan koordinasi mata-tangan sebesar 102,171 dengan nilai signifikansi sebesar $0,000<0,05$, karena $p$ $<0,05$. Ini artinya terdapat pengaruh interaksi antara metode latihan dengan koordinasi matatangan yang signifikan terhadap hasil servis atas bola voli.

Perhitungan pairwise comparisons menunjukkan bahwa kelompok-kelompok interaksi yang memiliki pengaruh secara signifikan adalah (1) JR_RENDAH dengan JR_TINGGI, 
(2) JR_RENDAH dengan MP_RENDAH, (3) JR RENDAH dengan MP_TINGGI, (4) JR TINGGI dengan MP_RENDAH, (5) JR TINGGI dengan MP_TINGGI, dan (6) MP_RENDAH dengan MP_TINGGI. Dengan demikian dapat disimpulkan bahwa: (a) jika metode latihan manipulasi jarak dengan koordinasi mata-tangan rendah dibandingkan dengan metode manipulasi jarak dengan koordinasi matatangan tinggi, terdapat pengaruh yang signifikan terhadap hasil servis atas, (b) jika metode latihan manipulasi jarak dengan koordinasi mata-tangan rendah dibandingkan dengan metode latihan massed practice dengan koordinasi mata-tangan rendah, terdapat pengaruh yang signifikan terhadap hasil servis atas (top spin), (c) jika metode latihan manipulasi jarak dengan koordinasi mata-tangan rendah dibandingkan dengan metode massed practice dengan koordinasi matatangan tinggi, terdapat pengaruh yang signifikan terhadap hasil servis atas, (d) jika metode latihan manipulasi jarak dengan koordinasi mata-tangan tinggi dibandingkan dengan metode massed practice dengan koordinasi mata tangan rendah, terdapat pengaruh yang signifikan terhadap hasil servis atas, (e) jika metode latihan manipulasi jarak dengan koordinasi mata-tangan tinggi dibandingkan dengan metode latihan massed practice dengan koordinasi mata-tangan tinggi, terdapat pengaruh yang signifikan terhadap hasil servis atas, (f) jika metode massed practice dengan koordinasi mata-tangan rendah dibandingkan dengan metode latihan massed practice dengan koordinasi mata-tangan tinggi, terdapat pengaruh yang signifikan terhadap hasil servis atas (top spin).

\section{Pembahasan}

Pengaruh antara Metode Latihan Massed Practice dan Metode Latihan Manipulasi Jarak terhadap Hasil Keterampilan Servis Atas Bola Voli

Dilihat dari rata-rata peningkatan hasil servis atas bola voli pada saat pretest dan posttes, selisih peningkatan pada metode latihan massed practice sebesar 28,58, sedangkan pada metode latihan manipulasi jarak servis adalah sebesar 13,5. Kesimpulan yang dapat diambil adalah bahwa metode latihan massed practice lebih baik daripada metode manipulasi jarak servis dalam meningkatkan keterampilan servis atas bola voli.

Metode massed practice yaitu mempraktikkan gerakan secara terus-menerus tanpa diselingi waktu istirahat (Singer, 1965). Latihan yang dilakukan secara terus-menerus yang dilakukan secara berulang-ulang tanpa istirahat akan berpengaruh pada daya tahan keseluruhan selain itu intensitas perlakuan secara terusmenerus akan meningkatkan kontrol gerakan pada saat melakukan suatu rangkaian gerakan. Anak latih akan mendapatkan gerak otomatisasi lebih cepat. Untuk meningkatan hasil servis atas bola voli dengan menggunakan metode latihan massed practice dapat melatih dua dasar komponen latihan sekaligus yaitu dapat melatih teknik sekaligus fisik atlet.

Latihan servis atas dengan manipulasi jarak servis merupakan bentuk latihan keterampilan yang dilakukan dari cara yang lebih mudah kemudian dilanjutkan ke tahap yang selanjutnya yang semakin sulit, yaitu dengan mengatur jarak servis.

Kelebihan metode ini adalah memperkenalkan bentuk perlakuan yang mudah dahulu kemudian berangsur-angsur ke perlakuan yang sesungguhnya, memberikan adaptasi pada kekuatan otot sehingga meminimalisasi terjadinya cedera. Apabila ditinjau dari kelebihan masing-masing, tampak bahwa metode latihan massed practice memiliki keung-gulan sedikit dibandingkan dengan metode latihan manipulasi jarak.

Pengaruh antara Koordinasi Mata-Tangan Tinggi dan Koordinasi Mata-Tangan Rendah terhadap Hasil Keterampilan Servis Atas Bola Voli

Koordinasi mata-tangan adalah hubungan harmonis dari mata-tangan yang terjadi pada satu gerakan. Dari hasil servis atas dapat diketahui anak latih yang memiliki kordinasi matatangan tinggi memiliki rata-rata nilai 41,18 dan anak latih yang memiliki koordinasi matatangan rendah memiliki rata-rata nilai 16,45 . Kesimpulan yang dapat diambil adalah bahwa anak latih yang memiliki koordinasi matatangan tinggi lebih baik daripada anak latih yang memiliki koordinasi mata-tangan rendah terhadap keterampilan servis atas bola voli.

Anak latih pada penelitian ini, berdasarkan hasil penelitian pada saat awal sebelum diberikan treatment (metode latihan), anak latih yang memiliki koordinasi mata-tangan tinggi keberhasilan saat melakukan servis atas lebih baik dan memiliki hasil (nilai) lebih tinggi dibandingkan dengan anak latih yang memiliki koordinasi mata-tangan rendah. hal ini dikarenakan bahwa dengan memiliki koordinasi mata- 
tangan yang baik anak akan mudah melakukan gerakan yang cukup kompleks seperti servis atas dengan harmonis.

Interaksi antara Metode Latihan Massed Practice dan Metode Latihan Manipulasi Jarak Servis serta Koordinasi Mata-Tangan Tinggi dan Rendah terhadap Hasil Keterampilan Servis Atas Bola Voli

Berdasarkan hasil yang telah dikemukakan pada hasil penelitian tersebut terdapat interaksi yang berarti antara metode latihan dan koordinasi mata-tangan tinggi dan rendah terhadap keterampilan servis atas bola voli pada anak latih kegiatan ekstrakurikuler SMP Negeri 1 dan SMP Negeri 3 Kalasan.

Berdasarkan data di atas diperoleh: (1) anak latih yang memiliki koordinai mata-tangan tinggi yang dilatih dengan metode latihan massed practice $\left(\mathrm{A}_{1} \mathrm{~B}_{1}\right)$ mengalami pening-katan terbesar yaitu sebesar 42,83, (2) anak latih yang memiliki koordinasi mata-tangan rendah yang dilatih dengan metode latihan manipulasi jarak servis $\left(A_{2} B_{2}\right)$ mengalami peningkatan pada urutan kedua sebesar 22,2, (3) anak yang memiliki koordinasi mata-tangan tinggi yang dilatih dengan metode latihan massed practice $\left(\mathrm{A}_{1} \mathrm{~B}_{2}\right)$ mengalami peningkatan pada urutan ketiga sebesar 14,3, (4) anak latih yang memiliki koorinasi mata-tangan tinggi yang dilatih dengan metode latihan manipulasi jarak servis $\left(\mathrm{A}_{2} \mathrm{~B}_{1}\right)$ juga mengalami peningkatan dengan urutan terendah sebesar 4, 8. Keefektifan metode latihan yang diterapkan untuk meningkatkan hasil servis atas bola voli tersebut dipengaruhi oleh tinggi atau rendahnya koordinasi matatangan yang dimiliki anak latih. Dan yang paling efektif adalah anak yang memiliki koordinasi mata-tangan tinggi.

Anak latih yang memiliki koordinasi mata-tangan tinggi lebih cocok mengggunakan metode latihan massed practice, kemudian pada anak latih yang memiliki koordinasi mata-tangan rendah lebih cocok dilatih dengan menggunkan metode latihan manipulasi jarak servis. Karena latihan dilakukan berulang-ulang di tempat yang sama (jarak servis yang sesungguhnya) maka anak latih akan belajar dari perlakuan yang sebelumnya agar dapat menghasilkan gerak yang lebih baik dari sebelumnya (triad and error). "Define massed practice more loosely as, a practice schedule in which the amount of rest between trials is short relative to the trial leght" (Murray \& Udermann, 2003, p. 19). Meskipun ada kekurangan dapat menyebab- kan kelelahan, secara lebih lanjut akan diperbaiki daya tahan anak latih. Untuk pengaruh metode latihan manipulasi jarak, sebenarnya juga memiliki pengaruh yang baik untuk anak latih, namun tidak begitu menyeluruh. Anak latih sering berubah fokus ketika ada peningkatan jarak servis. Metode latihan massed practice yang selalu fokus dari satu tempat sedangkan metode latihan manipulasi jarak yang selalu ada perubahan tempat servis inilah yang menyebabkan perbedaan antara perbedaan kedua metode latihan tersebut.

\section{SIMPULAN DAN SARAN}

\section{Simpulan}

Terdapat perbedaan pengaruh yang signifikan pada metode latihan massed practice dengan metode latihan manipulasi jarak servis terhadap peningkatan keterampilan servis atas bola voli pada anak latih ekstrakurikuler SMP Negeri 1 Kalasan dan SMP Negeri 3 Kalasan. Perbedaannya adalah metode latihan massed practice memberikan pengaruh lebih baik daripada metode latihan manipulasi jarak servis terhadap peningkatan keterampilan servis atas bola voli.

Terdapat pengaruh perbedaan yang signifikan antara anak latih yang memiliki koordinasi mata-tangan tinggi koordinasi matatangan rendah terhadap keterampilan servis atas bola voli pada anak latih ekstrakurikuler SMP Negeri 1 Kalasan dan SMP Negeri 3 Kalasan. Anak latih dengan kemampuan koordinasi matatangan tinggi dengan anak latih kemampuan koordinasi mata-tangan rendah memiliki perbedaan terhadap keterampilan servis atas bola voli. Anak latih yang memiliki koordinasi matatangan tinggi memiliki keterampilan servis atas bola voli lebih baik daripada anak latih yang memiliki koordinasi mata-tangan rendah.

Terdapat interaksi antara metode latihan servis dan koordinasi mata-tangan terhadap hasil servis atas bola voli pada anak latih ekstrakurikuler SMP Negeri 1 Kalasan dan SMP Negeri 3 Kalasan. Metode latihan massed practice lebih efektif digunakan untuk anak latih yang memiliki koordinasi mata-tangan tinggi, sementara metode latihan manipulasi jarak servis efektif digunakan untuk anak latih yang memiliki koordinasi mata-tangan rendah.

\section{Saran}

Metode latihan massed practice memiliki pengaruh yang lebih baik dalam meningkatkan 
hasil servis atas, sehingga pelatih atau pembina olahraga sebaiknya memilih metode latihan massed practice dalam upaya meningkatkan hasil servis atas. Metode latihan messed practice dan metode latihan manipulasi jarak servis perlu memperhatikan faktor koordinasi mata-tangan serta prasarana dan sarana yang tersedia dalam meningkatkan hasil servis atas. Dalam upaya meningkatkan hasil servis atas, anak latih yang memiliki koordinasi mata-tangan tinggi akan lebih tepat dan efektif, jika dilatih dengan metode latihan massed practice. Dalam upaya meningkatkan hasil servis atas, anak latih yang memiliki koordinasi mata-tangan rendah akan lebih tepat dan efektif, jika dilatih dengan metode latihan manipulasi jarak servis. Pelatih atau pembina olahraga disarankan merancang program latihan yang tepat dan terencana sesuai dengan cabang olahraga masing-masing, mengingat kebutuhan hasil servis atas setiap cabang olahraga berbeda-beda dan belum tentu suatu metode latihan sesuai atau cocok bagi semua kelompok.

\section{DAFTAR PUSTAKA}

Bompa, T. O. (1999). Periodization: Theory and methodology of training. Champaign, United States: Human Kinetics.

Bompa, T. O., \& Haff, G. (2009). Periodization: theory and methodology of training. Iowa: Human Kinetics.

Harsono. (2004). Perencanaan program latihan. Bandung: Tarsito.

Magill, R. A. (2011). Motor learning and control: Concepts and applications. New York, N.Y.: McGraw-Hill.

Miller, D. K. (David K. (2013). Measurement by the physical educator: why and how (7 edition). New York, United States: McGraw-Hill Education.

Muhajir. (2004). Pendidikan jasmani: Teori dan praktek SMA untuk kelas $X$. Jakarta: Erlangga.
Murray, S. R., \& Udermann, B. E. (2003). Massed versus Distributed Practice: Which is Better? CAHPERD Journal, 28(1), 1922. Retrieved from http://www.krigolsonteaching.com/uploads /4/3/8/4/43848243/massedversusdistribute dpracticewhichisbetter.pdf

Nurhasan. (2000). Tes dan pengukuran pendidikan olahraga. Jakarta: Kurunika.

Presiden Republik Indonesia. Undang-Undang Republik Indonesia nomor 20 tahun 2003 tentang sistem pendidikan nasional, Pub. L. No. 20 (2003). Retrieved from http://sindikker.dikti.go.id/dok/UU/UU202003-Sisdiknas.pdf

Rahyubi, H. (2012). Teori-teori belajar dan aplikasi pembelajaran motorik: Deskripsi dan tinjauan kritis. Bandung: Nusa Media.

Singer, R. N. (1965). Massed and distributed practice effects on the acquisition and retention of a novel basketball skill. Research Quarterly. American Association for Health, Physical Education and Recreation, 36(1), 68-77. http://doi.org/10.1080/10671188.1965.106 14658

Sudjana. (2002). Desain dan analisis eksperimen (Ed. 4). Bandung: Tarsito.

Suganda, M. A., \& Suharjana, S. (2013). Pengembangan model pembelajaran bolavoli pada siswa sekolah dasar kelas atas. Jurnal Keolahragaan, 1(2), 156-165. http://doi.org/10.21831/JK.V1I2.2571

Sugiyono. (2010). Metode penelitian pendidikan: Pendekatan kuantitatif, kualitatif, dan $R \& D$. Bandung: Alfabeta.

Suharno, H. (1998). Ilmu kepelatihan olahraga. Bandung: PT Karya Ilmu.

Viera, B. L., Fergusson, B. J., \& Monti. (2000). Bola voli tingkat pemula. Jakarta: Raja Grafindo Persada. 